\title{
Construction materials in estuaries: reduction in the epibiotic community on chromated copper arsenate (CCA) treated wood
}

\author{
Judith S. Weis ${ }^{1}$, Peddrick Weis ${ }^{2}$ \\ ${ }^{1}$ Department of Biological Sciences, Rutgers University, Newark, New Jersey 07102, USA \\ ${ }^{2}$ Department of Anatomy, New Jersey Medical School, Newark, New Jersey 07103, USA
}

\begin{abstract}
Boards of CCA-treated wood, control (untreated) wood, and recycled plastic 'lumber' were placed into an estuary (Fort Pond, Southampton, NY, USA) in early May and examined monthly for abundance of species. One set of boards was left in the water continuously for 5 mo. Another set was renewed each month; after counting, organisms were removed and analyzed for dry weight and metal concentrations. A further set, placed in Accabonac Harbor, East Hampton, NY, in early July, compared CCA-treated wood that had not been impregnated well (green did not extend to inner portions), wood that had been well impregnated, and control wood. These boards were left in the water for $2 \mathrm{mo}$, and examined every $2 \mathrm{wk}$. Treated wood had a reduced number of species, lower diversity index, fewer barnacles (Balanus eburneus) and reduced growth of the barnacles that settled, fewer Membranipora and reduced growth of Membranipora colonies, fewer macroalgae, and fewer amphipods, compared to control wood and plastic. The bryozoan Bugula turnta, however, was found at great density on the treated wood. Biomass was lower on treated wood compared to control wood and plastic, and accumulations of $\mathrm{Cu}, \mathrm{Cr}$, and As were found. Barnacles initially avoided settling on plastic, but after 1 mo exceeded those on control wood. The communities in the 2 estuaries differed: e.g. at Accabonac species number was lower, there was less algae, bryozoans were absent, and barnacles were more dominant.
\end{abstract}

\section{INTRODUCTION}

Wooden structures in marine environments are subject to decay, so wood is often treated with preservatives such as creosote and pentachlorophenol. Currently most wood is pressure treated with chromium, copper and arsenic (CCA), which gives the wood a greenish tinge. The process of preserving wood with these elements is called 'Wolmanizing,' and generally uses oxides $\left(\mathrm{CrO}_{3}, \mathrm{CuO}\right.$, and $\left.\mathrm{As}_{2} \mathrm{O}_{5}\right)$. While wood designed to be placed on land generally receives $0.4 \mathrm{lb} \mathrm{ft}^{-3}\left(6.4 \mathrm{~kg} \mathrm{~m}^{-3}\right)$, wood designed for marine use receives $1.5 \mathrm{lb} \mathrm{ft}^{-3}\left(24 \mathrm{~kg} \mathrm{~m}^{-3}\right)$, or in some areas, $2.5 \mathrm{lb}$ $\mathrm{ft}^{-3}\left(40 \mathrm{~kg} \mathrm{~m}^{-3}\right)$. High concentrations of $\mathrm{Cr}, \mathrm{Cu}$, and $\mathrm{As}$ were found in soils in the vicinity of a wood treatment facility in Denmark (Lund \& Fobian 1991). Runoff from a wood preserving facility allowed $\mathrm{Cu}, \mathrm{Cr}$, and $\mathrm{As}$ to accumulate in downstream pond sediments; this was associated with reduced species diversity and numbers of macroinvertebrates (Neary et al. 1989).

All 3 metals are known to be toxic to aquatic biota. Arsenic is carcinogenic, mutagenic and teratogenic. It exists in several different oxidation states of which $\mathrm{As}(\mathrm{III})$ and $\mathrm{As}(\mathrm{V})$ are prevalent. As(III) is more toxic and less prevalent than As(V). Arsenate is readily taken up by phytoplankton to enter food webs (Sanders \& Windom 1980). Chromium exists in the aquatic environment as chromate [Cr(VI)], which is carcinogenic and mutagenic (Sanders \& Riedel 1987). Under conditions of reduced oxygen, it may be reduced to $\mathrm{Cr}$ (III) which is considerably less toxic. Copper is used as an algicide and molluscicide. It is needed as a micronutrient, but can be toxic at higher levels. The free ion form is the toxic species, while most copper is bound to organic material in the aquatic environment (Newell \& Sanders 1986). There is con- 
cern that CCA-treated wood may have toxic effects (beyond its intended use), but there have been few studies directed towards ascertaining effects of this pressure-treated wood in the aquatic environment.

The U.S. Environmental Protection Agency has jurisdiction over pressure-treated wood under the Federal Insecticide, Fungicide and Rodenticide Act (FIFRA), but it has done little to regulate these products. It has, however, designated waste streams from wood preserving facilities as 'hazardous waste' under the Resource Conservation and Recovery Act (RCRA) (U.S. E.P.A. 1990).

Warner \& Solomon (1990) demonstrated that all 3 metals leach from treated wood placed in fresh water, and that leaching is greatest at low $\mathrm{pH}$. Sanders (pers.

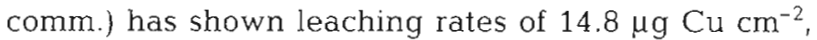
$0.65 \mu \mathrm{g} \mathrm{Cr} \mathrm{cm}{ }^{-2}$, and $28.4 \mu \mathrm{g} \mathrm{As} \mathrm{cm}^{-2}$ from wood treated with $6.4 \mathrm{~kg} \mathrm{~m}^{-3}$ placed in water of $12 \%$ salinity for 1 wk. Previous work in our laboratory (Weis et al. 1991) showed that all 3 chemicals leach into sea water, and that leachates are toxic to a variety of estuarine biota, including algae, snails, crabs, and fish embryos. Leaching for $2 \mathrm{wk}$ in $28 \%$ sea water was $30 \mu \mathrm{g} \mathrm{cm} \mathrm{cm}^{-2}$ $\mathrm{Cu}, 0.8 \mu \mathrm{g} \mathrm{cm}^{-2} \mathrm{Cr}$, and $8.0 \mu \mathrm{g} \mathrm{cm}^{-2}$ As. Leaching rates generally decreased over time. A subsequent study demonstrated toxic effects of leachates in a sea urchin fertilization bioassay (Weis et al. 1992). Copper leached to the greatest extent in both the Warner \& Solomon study and in our studies, despite the fact that chromium is present in the greatest amount in the wood.

We have also compared the toxicity of treated wood and recycled plastic 'lumber,' another possible construction material for bulkheads (retaining walls along the waterfront) made from mixed, post-consumer plastics. In laboratory studies, plastic proved to be far less toxic than treated wood to various estuarine species, although it did leach a large number of organic chemicals in low amounts (Weis et al. 1992)

These previous studies were performed in confined aquaria in which concentrations could build up to highly toxic levels, unlike the situation in the field where dilution and water movements would reduce potential effects. Recent work is focusing on more environmentally realistic experiments. The impact of a CCA bulkhead in an estuary will be determined by several factors including: (1) the amount of chemicals leached, determined by the area of bulkhead leaching, and the leaching rate, determined by the nature of the wood, the amount of metals impregnated in it, how long it has been leaching, and other factors; (2) metal speciation; (3) the degree of dilution and dispersion by water movements; (4) the adsorptive capacity of the sediments, determined primarily by particle size distribution; (5) sediment transport by currents and biotur- bation; and (6) the rate of uptake by the fouling community, determined by the particular species and their density.

One route by which chemicals leached from treated wood can enter aquatic ecosystems is through water dissolution and subsequent uptake by epibiota on the wood. Thus, this community of organisms might be altered by the nature of their substratum. (Wood preservation is designed to inhibit decay, not 'fouling.') We here report the results of a field study, designed to investigate the nature of the epibiotic community that forms on panels of these different materials submerged in an estuary.

\section{MATERIALS AND METHODS}

One-foot lengths of $2^{\prime \prime} \times 6^{\prime \prime}$ dimensional lumber $(4 \times$ $14 \times 30.5 \mathrm{~cm}$ ) of treated yellow pine, control pine, and recycled plastic were suspended in the water. The treated wood was $1.5 \mathrm{lb} \mathrm{ft}^{-3}\left(24 \mathrm{~kg} \mathrm{~m}^{-3}\right)$ material donated by BB\&D Lumber in Speonk, New York, USA (courtesy of Thomas Samuels). The recycled plastic lumber was produced at the Center for Plastic Recycling Research, Rutgers University (courtesy of Dr Thomas Nosker). Boards were attached by means of screw eyes, and were weighted down on the other end, so that they hung vertically in the water, an orientation like that of wood in bulkheads. Eighteen panels were submerged at any given time: 3 of each material (treated wood, control wood, and plastic) that remained in the water, and 3 of each that were removed at monthly intervals and replaced with new panels. At the beginning of May 1991, panels were placed into Fort Pond in Southampton, New York, an estuary with a considerable amount of bulkheading (upright walls) and boating activity. Panels were examined at 2 wk intervals by removing them from the rope, placing them in a pan of sea water and counting and identifying all resident organisms. Diameters of barnacles (Balanus eburneus) and of colonies of the bryozon Membranipora were also measured. At the end of each month, the community that had developed on each of the 1 mo boards was scraped into individual jars and analyzed for biomass (dry weight) and metal concentration. These boards were then replaced by another 9 boards. This experiment continued for 4 summer months.

Another set of 12 boards was placed in early July in Accabonac Harbor, in East Hampton, New York, in an area without bulkheading and with little boat traffic and much less shoreline development. The temperature and salinity regimes at the 2 sites were very similar, and both sites are situated in cul-de-sacs, receiving fresh water only from marsh surface run-off and underground springs. The Accabonac boards 
were made of control wood ( $n=6)$, treated wood that appeared to have been poorly impregnated, i.e. did not have the typical green color in interior portions ( $\mathrm{n}=3$ ), and treated wood that had been heavily impregnated $(n=3)$. These panels were examined and the resident biota recorded; none were scraped off.

Metal analysis was done on the scrapings by first drying at $150^{\circ} \mathrm{C}$, wet-ashing a subsample (2 to $3 \mathrm{~g}$ ) in $3: 1 \mathrm{HNO}_{3}: \mathrm{HClO}_{4}$ (Baker reagents 'for trace metal analysis', where available), and determining $\mathrm{Cu}$ and $\mathrm{Cr}$ by flame-aspiration in a Perkin-Elmer 403 atomic absorption spectrophotometer. As was determined in the same instrument following hydride generation. Quality control was assured by including NIST Standard Reference Materials oyster powder and orchard leaves (SRM 1566 and SRM 1571; National Institute of Standards and Technology, Gaithersburg, MD).

Diversity of the community was calculated by means of the (non-parametric) ShannonWiener diversity index (counting each colony of bryozoans as 1 individual). All other data were analyzed by $t$-test and analysis of variance, using the $5 \%$ level of significance.

\section{RESULTS}

During this study, the temperature in Fort Pond increased from about $13^{\circ} \mathrm{C}$ in early May to $24{ }^{\circ} \mathrm{C}$ in mid-August. The salinity remained between 28 and $30 \%$. On the boards renewed monthly, as well as on the permanent boards, species richness, Shannon-Wiener diversity index, and biomass increased over the course of the summer. There was relatively little settlement in May, although there were large numbers of gastropod egg cases (probably Nassarius obsoletus) on both control wood and plastic, reducing the diversity on these panels. Boards of each type at each location were generally quite similar to one another. Dominant organisms in the community were the barnacle Balanus eburneus, the bryozoan Membranipora sp., and, in Fort Pond only, the bryozoan Bugula turrita. Additional species frequently noted were the tunicate Molgula manhattensis, amphipods (mostly Gammarus mucronatus, Microdeutopus gryllotalpa, and Ampithoe valida), and the polychaete Polydora ligni. Common macro- algae included Cladophora sp, Ectocarpus sp., Polysiphonia sp., Ulva lactuca, Enteromorpha intestinalis, Ceramium sp, and Cystoclonium sp. Striking differences were seen between the biota that settled on.

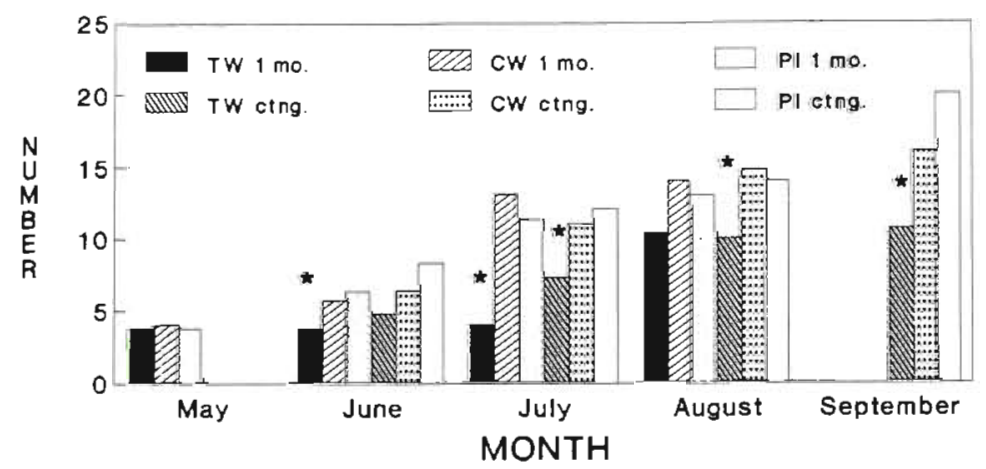

Fig. 1. Number of species found on monthly (1 mo) and continuing (ctng) panels in Fort Pond. ( $\star$ ) Statistically different from control wood. For Fort Pond panels: $\mathrm{TW}=$ treated wood, $\mathrm{CW}=$ control wood, $\mathrm{Pl}=$ plastic. Significant F-values: June (1 mo), 17.33; June (ctng), 10.11; July (1 mo), 88.43; July (ctng), 23.29; August (ctng), 9.05; September, 11.38

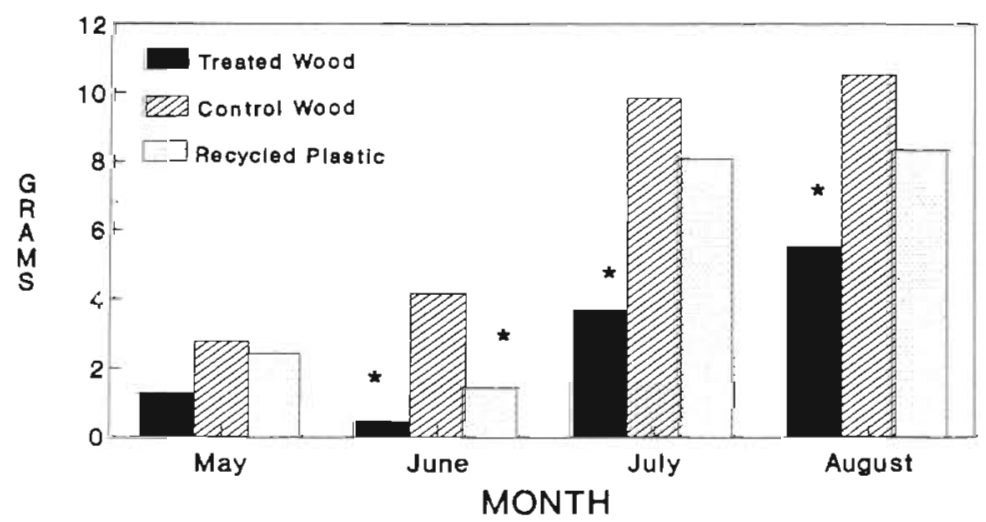

Fig. 2. Biomass (dry wt) of epibiota on monthly panels in Fort Pond (*) Significant F-values: June, 15.68; July, 24.69; August, 15.62

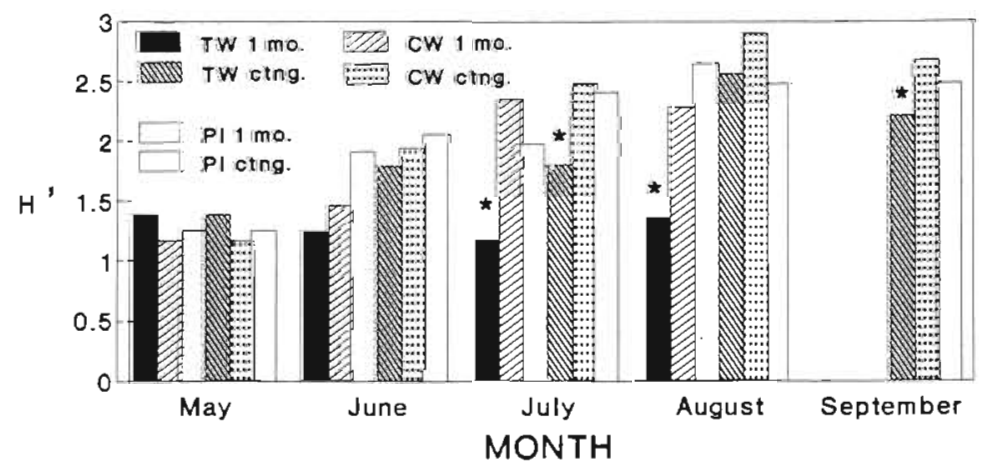

Fig. 3. Diversity (Shannon-Wiener) on monthly and continuing panels in Fort Pond. (*) Significant by probabilities described in text 


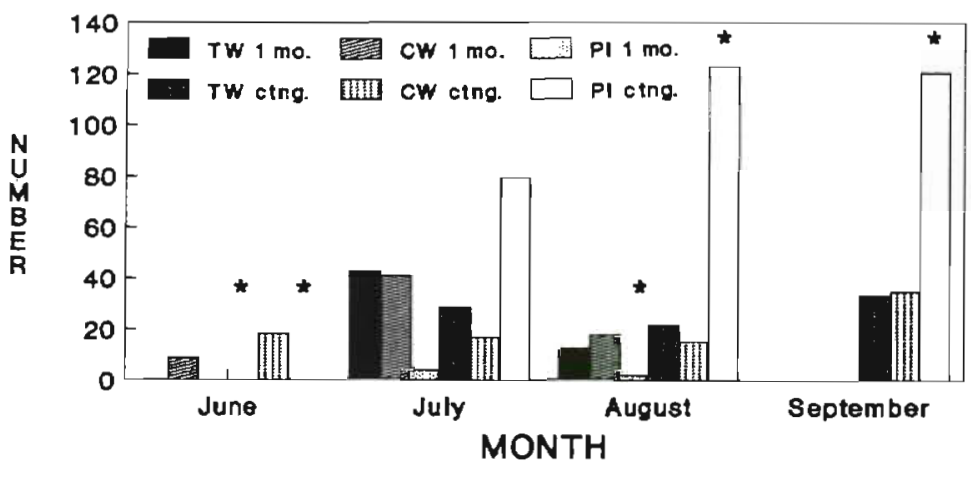

Fig. 4. Number of barnacles (Balanus eburneus) on monthly and continuing panels in Fort Pond (none found on TW or Pl in June). (*) Significant $F$-values: June (ctng), 26.94, August (1 mo), 10.29; August (ctng), 6.37; September, $4.74(\mathrm{p}=0.058)$

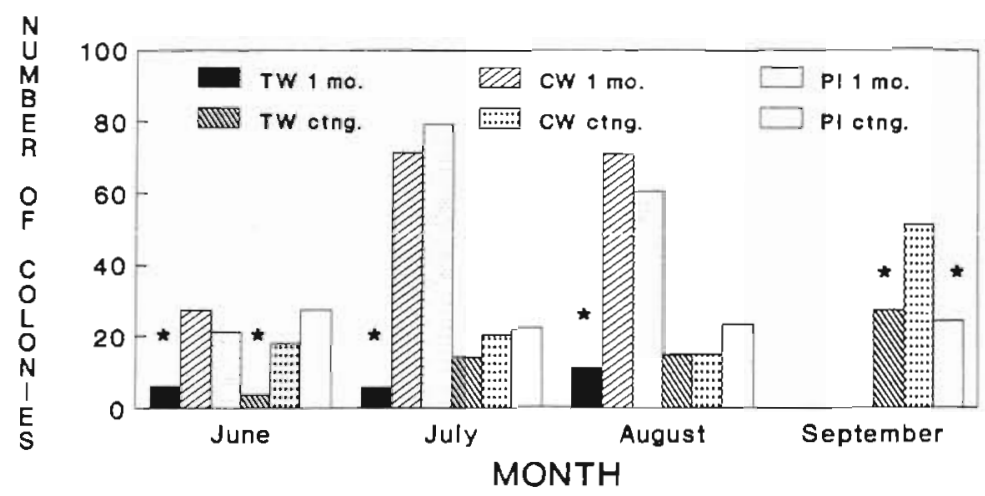

Fig. 5. Number of Membranipora colonies on monthly and continuing panels in Fort Pond. Significant F-values: June (1 mo), 15.42, June (ctng), 11.88; July (1 mo), 145.59; August (1 mo), 26.21; September, 6.61

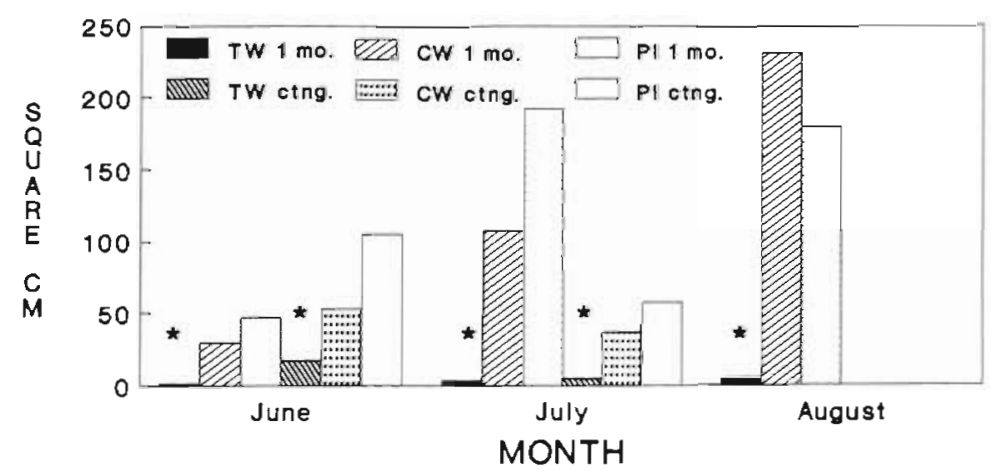

Fig. 6. Area covered by Membranipora colonies on monthly and continuing panels. Significant F-values: June (1 mo), 6.27; June (ctng), 12.94; July (1 mo), 7.23; July (ctng), 18.39; August (1 mo), 64.4

treated wood and those that settled on control wood or plastic. Fewer species were found on the treated wood (Fig. 1). Biomass was considerably less at each measurement (Fig. 2), as was the diversity index (Fig. $3)$. On the continuing boards, differences in diversity index were less striking than on the monthly boards. The existence of only 3 replicates of each material precluded use of most nonparametric statistical tests for significance, since these require 4 or more replicates. However, on both sets of boards (continuing and monthly) for both July and August, and on the continuing boards in September, there was no overlap between the diversity indices on the treated wood panels and on the control wood or plastic panels. (The probability that the 3 smallest values out of 9 would all lie in the same group of 3 is 0.036 , thus meeting the standard for statistical significance.)

Plastic generally had somewhat lower biomass, but diversity and species numbers were comparable to that of control wood. Barnacles appeared to avoid settling on 'fresh' plastic, but subsequently colonized plastic most readily and grew there most successfully (Fig. 4), presumably after establishment of a microfouling slime layer. While Membranipora settlement and growth was generally somewhat lower on control wood than plastic, it was greatly reduced on the treated wood (Figs. $5 \& 6$ ). After 3 mo of growth on the continuing panels, colonies were largely dead or overgrown by other organisms and could not be accurately measured. This may indicate that this species is representative of early succession. In contrast, Bugula settled most readily on the treated wood in its first month of submersion (Fig. 7), but on the continuing panels became most prevalent on plastic by late August. Both these species of bryozoans were found preferentially at the lower ends of the boards, while barnacles tended to prefer the upper ends.

Analysis of metal content revealed that very high accumulation of all 3 metals occurred in the epibiotic community on the CCA boards (Figs. 8 \& 9). The analysis was done on the whole scrapings, so does not distinguish among different species. The data shown are means of the levels of the 3 replicate boards of each type.

The community that developed on the Accabonac Harbor boards was different, in that far less algae of all kinds were present (with Ceramium sp. being the most abundant and Ulva lactuca and Enteromorpha intestinalis present also). Barnacles were by far the dominant species, and Bugula was totally absent. The ascidian Molgula man- 
hattensis was a more consistant member of this community, though only 1 or 2 were present on each (control) board. Overall species numbers were lower on these boards compared with the more developed Fort Pond Bay. Striking differences were noted between control and treated wood and between the panels that had been poorly preserved and those that had been well preserved. Initially, species numbers were lower in the well-preserved than the poorly preserved wood, as was the size of Membranipora colonies (Figs. $10 \& 11$ ). Both were consistently lower than the control wood. Membranipora coverage remained reduced on both types of treated wood compared to the control wood. While the number of Membranipora colonies was lowest in the well-treated wood at $1 \mathrm{mo}$, by 2 mo all 3 substrates were comparable in terms of numbers of colonies (Fig. 12). Since number of colonies reflects larval settlement and colony size reflects growth, it appears that growth of colonies (dependent on asexual reproduction) rather than larval settlement was more inhibited by the treated wood. It was interesting to note that the piece of control wood that was closest to the treated wood showed much less colonization than the other 5 pieces of control wood. This may indicate that the influence of the chemicals leaching from the treated wood extends beyond the immediate surface of that wood itself. (The boards were about $8 \mathrm{~cm}$ apart.)

While barnacles settled sooner on the control wood and the poorly treated wood, a very large settlement of barnacles on the well-preserved wood occurred in late July, resulting in very high density but very small size, compared to those on the other 2 materials (Fig. 13). Additional barnacle settlement occurred in August on the control wood, resulting in a reduced diversity index. However, the size differential persisted, and average barnacle size at the end of September was: control wood, $11.1 \pm 0.4 \mathrm{~mm}$ (SE); poorly treated wood, $10.1 \pm 0.8 \mathrm{~mm}$; and well-treated wood, $8.0 \pm 0.6 \mathrm{~mm}$, indicating that barnacle growth on the treated wood was reduced compared to control wood. Sizes of barnacles on Fort Pond boards were: CCA wood, $9.0 \pm 1.0 \mathrm{~mm}_{i}$ control wood, $11.0 \pm 0.6 \mathrm{~mm}$; and plastic, $13.8 \pm 0.5 \mathrm{~mm}$, indicating fastest growth on plastic. This set of barnacles in Accabonac

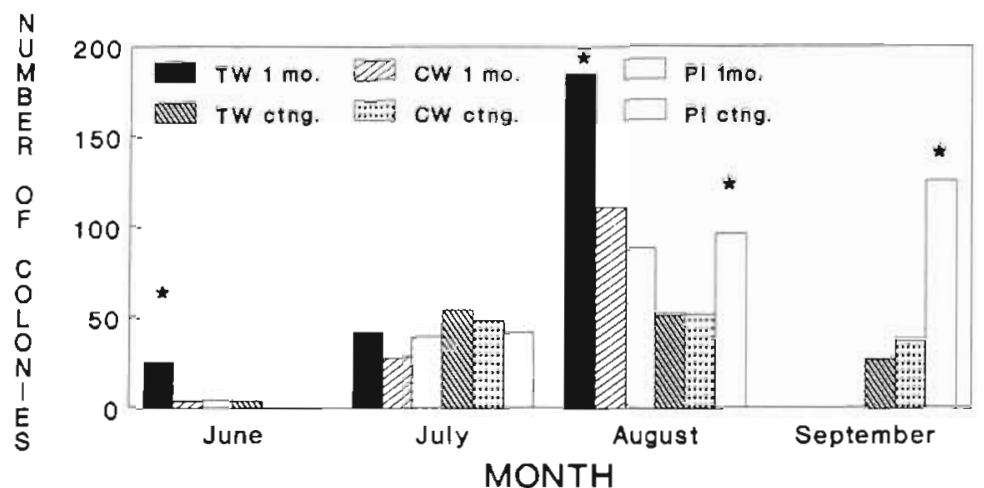

Fig. 7. Number of Bugula colonies on monthly and continuing panels Significant F-values: June $(1 \mathrm{mo}), 8.05$; August (1 mo), 41.05; August (ctng), 12.86; September, 16.55

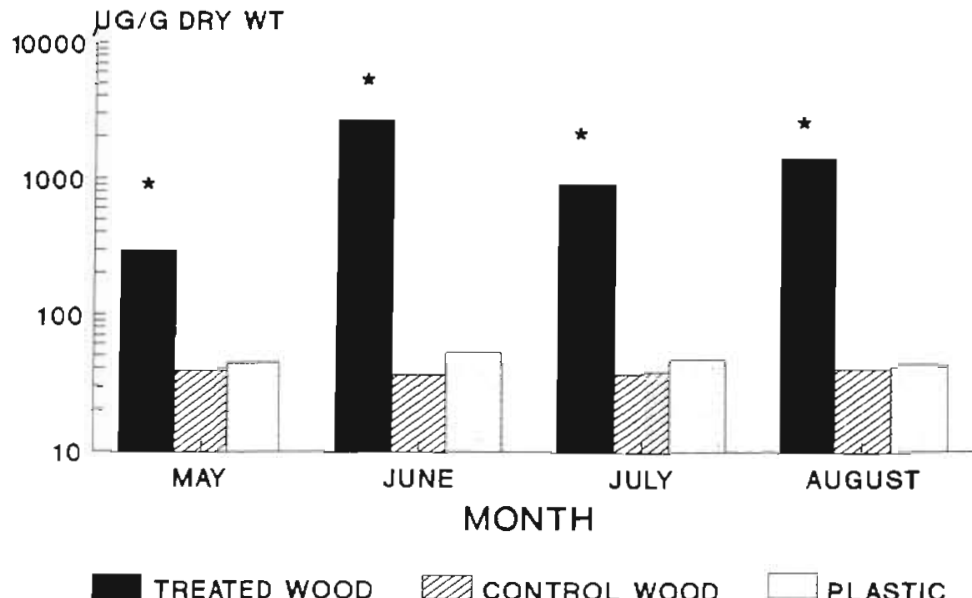

Fig. 8. Copper uptake by epibiota on monthly panels in Fort Pond

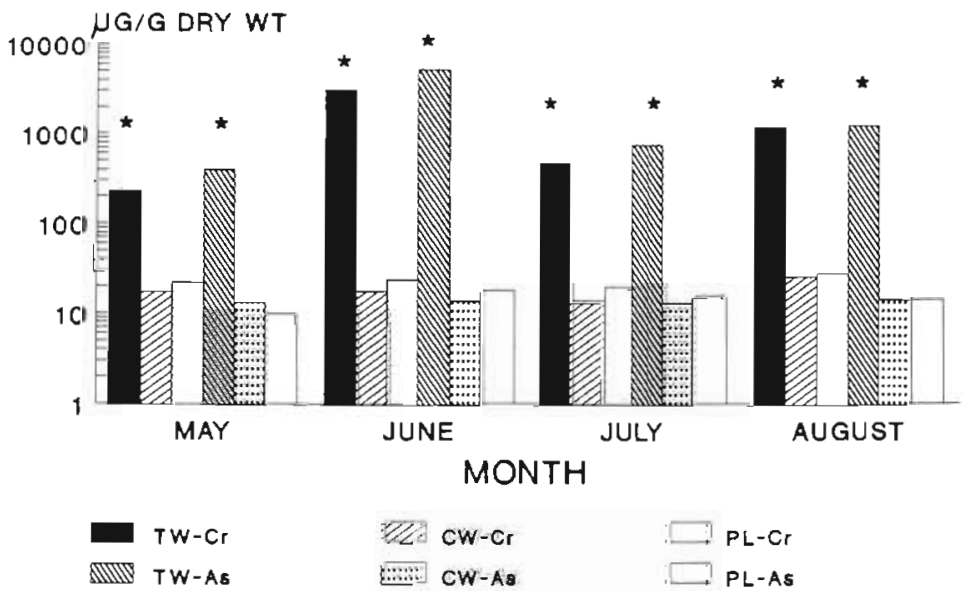

Fig. 9. Chromium and arsenic uptake by epibiota on monthly panels 


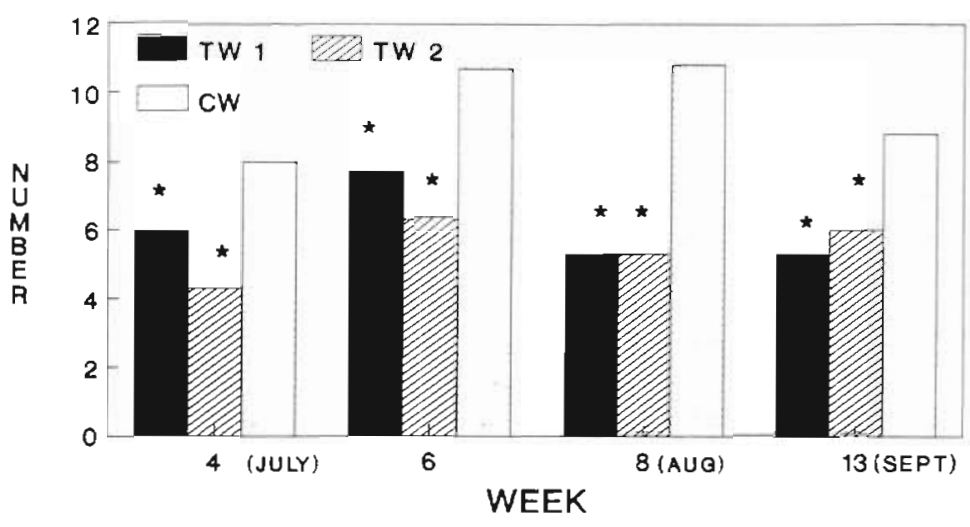

Fig. 10. Species richness on panels in Accabonac Harbor. Significant Fvalues: July, 20.66; $6 \mathrm{wk}, 18.14$; August, 50.0; September, 5.64. For all Accabonac panels, TW1 = poorly preserved (green did not penetrate into inner portions); TW2 $=$ well-preserved

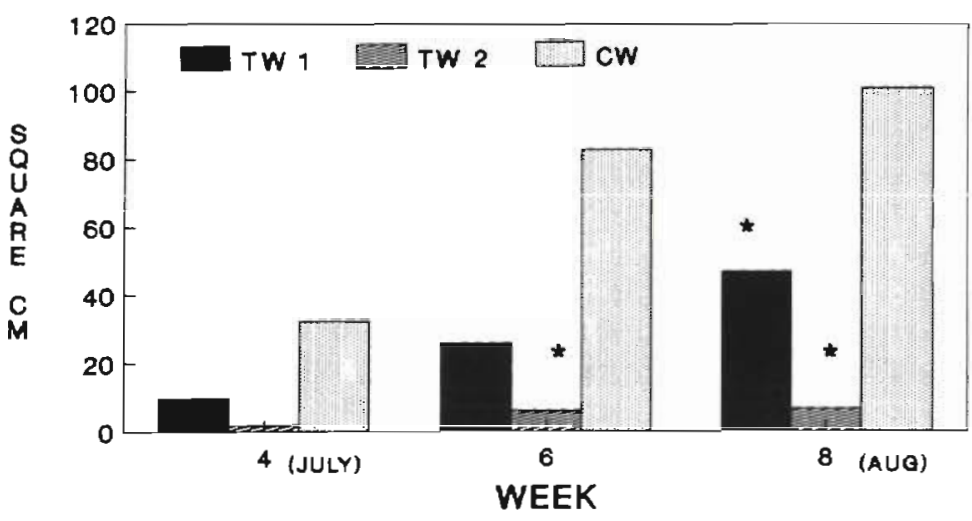

Fig. 11 Membranipora coverage on panels in Accabonac Harbor Significant F-value: August, 8.20

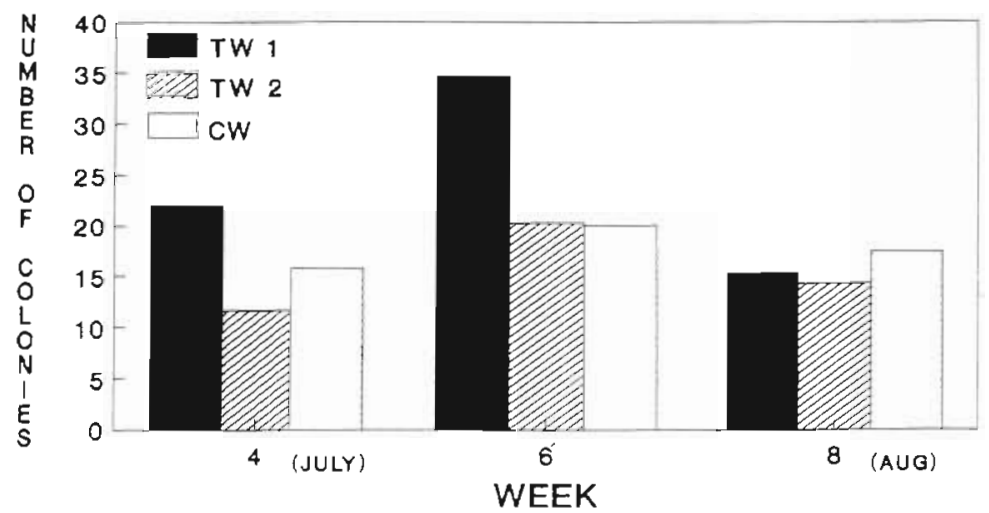

Fig. 12. Number of Membranipora colonies on Accabonac panels wood with those of the control wood or poorly treated panels.

When a dip net was used while lifting the boards from the water, large numbers of grass shrimp Palaemonetes pugio, as well as a few mud crabs Rhithropanopeus harrissi were found associated with the control wood panels, while smaller numbers were found associated with the treated boards (Fig. 15) That the shrimp were truly associated with the panels and not just accidentally caught in the net was demonstrated by returning them to the water and seeing them swim immediately to the boards. Fewer shrimp were found associated with the Fort Pond boards, but greater numbers of amphipods were found. Using a dip net at Fort Pond revealed a number of naked gobies Gobiosoma bosci and juvenile blue crabs Callinectes sapidus consistently associated with these panels.

\section{DISCUSSION}

Biological effects of CCA wood were apparent in this study. Fewer species, fewer individuals, and lower biomass were found on these treated panels compared to control wood and recycled plastic. The scarcity of organisms on all surfaces of the treated wood implies that chcmicals leach from all sides of the boards, not just the recently cut ends, as might have been the case. The only organism that did not appear to be inhibited from settling and growing on the treated wood was the bryozoan Bugula turrita, a species with a small area of attachment to the substrate. A possible reason for the apparent enhanced settlement on treated wood may be that there is less competition from algae and other epifauna for space on the treated wood. Settlement on the recycled plastic was, in many ways, comparable to that on the control wood. Substratum type has been previously noted to influence species composition of a hard substrate community. Hoagland \& Crocket (1.979) found greater number of species settling on aluminum panels than on wood or cement.

Harbor also reduced the diversity index of the wellpreserved wood and control. wood (Fig 14), while the diversity index of the poorly preserved wood was higher than that of the control wood. There was no overlap of the diversity indices of the well-treated
The initial avoidance of plastic by barnacles and preference for plastic by bryozoans may be related to surface wettability of plastic compared to control barnacles settle preferentially on surfaces with higher wood. Rittschof \& Costlow (1989) have shown that 
initial wettability, while bryozoans tend to settle on surfaces with lower wettability. Thus, surface chemistry can play a role in determining the distribution of barnacles and bryozoans. Despite the initial delay in settlement of plastic by barnacles, by August they had attained the largest numbers and largest size on the plastic panels, indicating faster growth.

Bryozoans (especially Membranipora) tended to settle on lower portions of the boards. This was also observed by Loveland \& Shafto (1984) in Barnegat Bay (NJ, USA) panels, and may be due to light avoidance by larvae, avoidance of competition for surface area, or other factors.

Previous work on hard substrate communities demonstrated that initial community development is unpredictable, based on larvae available for settling at particular times and in particular places. Subsequent changes in species composition depended largely on the ability of larvae to invade existing assemblages (Sutherland \& Karlson 1977. Menge 1991). Osman (1977) determined that 5 factors were primarily responsible for the development and distribution of the epifaunal community: selection by larvae of attachment sites, seasonal changes in larval abundances, biological interactions among species (primarily competition for space, and predation), the size of the substratum, and physical disturbance of the substrate (due to waves). Osman (1978) noted that smaller rocks are disturbed more often than larger ones. Hurricane Bob struck Long Island a week before the late August counts, but did not appear to have any effect on the biota on the panels.

Farrell (1991) studied succession in rocky intertidal communities on the Pacific coast and found a predictable general sequence of settlement of the barnacle Chthamalus dalli, followed by Balanus glandula, followed by 3 species of macroalgae. He found that algal settlement was dependent on alteration of the substrate by Balanus tests. Sousa (1979), however, determined that Ulva lactuca could inhibit the recruitment of red algae.

Physical factors such as shade and sunlight can affect the success of certain species of barnacles (Denley \& Underwood 1979). Salinity is another factor determining the particular species present in a hard substrate community (Loveland \& Shafto 1984). The salinities at both sites were 28 to $30 \%$; nevertheless, there were

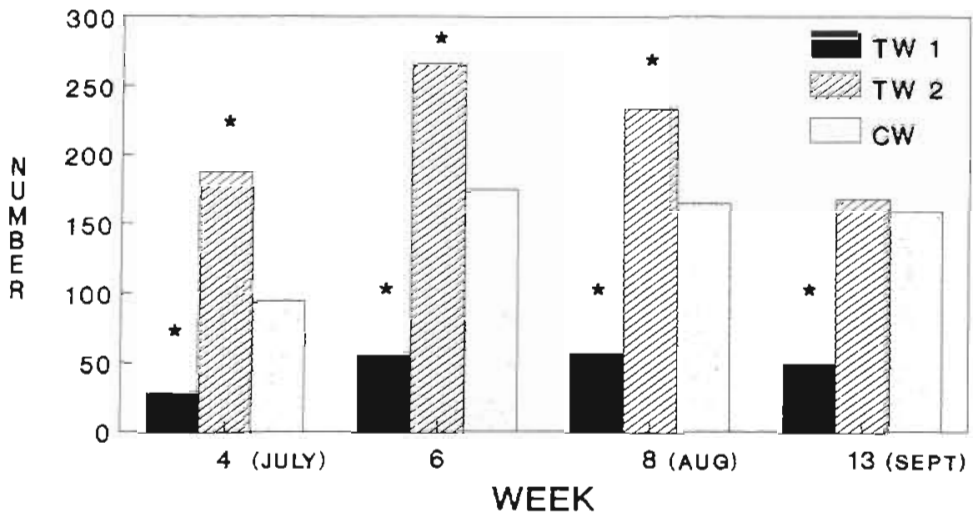

Fig. 13. Number of barnacles on Accabonac panels. Significant $F$-values: July, 71.82; 6 wk, 28.87; August, 18.90; September, 8.49

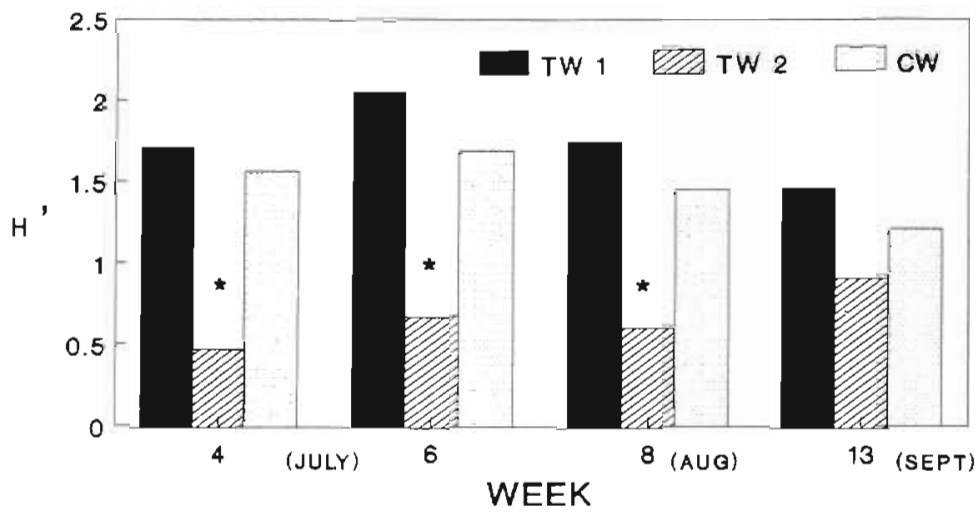

Fig. 14. Diversity index on Accabonac panels. ( $\star$ ) Significant according to probability described in the text

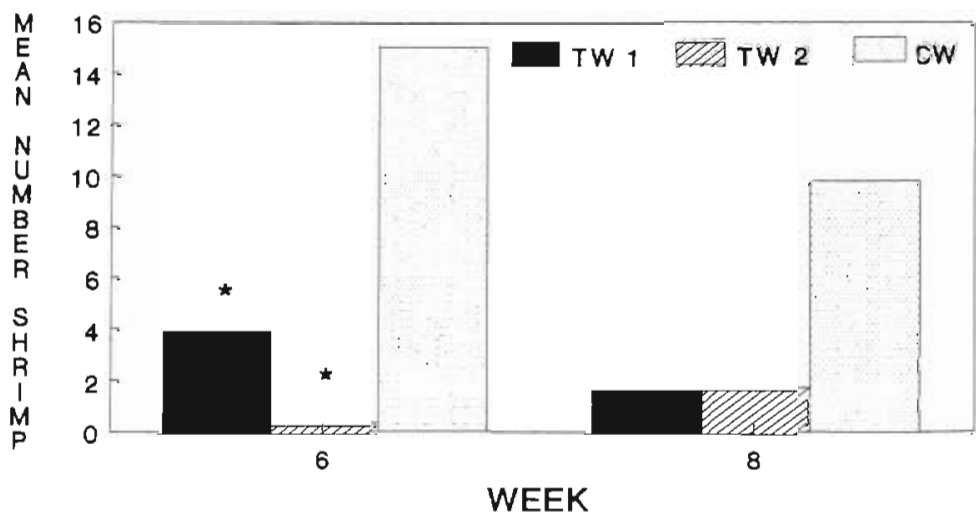

Fig. 15. Number of grass shrimp Palaemonetes pugio associated with Accabonac panels. Significant $F$-value: $6 \mathrm{wk}, 8.14$

still differences between the sites, with the less developed site showing less diversity, fewer species, and fewer numbers than the more disturbed site. One possible reason for this unexpected finding might be elevated nutrient levels that might be found in Fort Pond, although we have not measured nutrients. 
High concentrations of metals were taken up into the biota that settled on the treated wood. Metal levels in the biota on the panels were 2 orders of magnitude higher than those found in samples of Enteromorpha intestinalis and Ulva lactuca picked off a CCA wood dock, although those levels were also elevated compared to control specimens (Weis \& Weis in press). This difference may be due to the age of the dock ( 2 to $3 \mathrm{yr}$ in the water, thus leaching more slowly) compared to the fresh wood used in the monthly boards. It also may be that the epifauna scraped off the boards accumulates more metals than algae. In addition, the epibiota were scraped off the boards so that the sites of attachment were included in the samples, while the algae removed from the dock were picked by hand, probably leaving the attachment sites behind on the wood. Particles of wood may also have been inadvertently included in some of the scrapings. (Perhaps the high levels seen in the June scraping may have been due to overzealous scraping, although no visible pieces of wood were included.)

Ulva lactuca has been shown to be a useful monitor for environmental levels of some metals including copper (Ho 1990). Macroalgae in general have been found to be useful as monitors of metals in aquatic environments (Bryan \& Hummerstone 1973). Green algae have even been proposed for use in removing trace metals from water (Sneddon \& Pappas 1991). In our earlier laboratory experiments, $U$. lactuca was quite sensitive to leachates from CCA wood (Weis et al. 1991), so it was unexpected to find it growing on CCA wood in the field. There have been a number of studies showing adaptive mechanisms in algae to metals, including active exclusion of copper (Hall et al. 1979) and the use of storage sites within tissues for internal detoxification (Reed \& Moffat 1983). These authors found copper-tolerant strains of algae growing on vessels coated with copperbased antifouling paints. Such mechanisms may also be operative in the algae that grow on the treated wood.

Barnacles (Semibalanus balanoides and Balanus crenatus) have also been found to be useful monitors for heavy metals including $\mathrm{Cu}, \mathrm{Zn}$ and $\mathrm{Pb}$ (White 1990). They sequester $\mathrm{Cu}$ and $\mathrm{Zn}$ in parenchyma cells below the gut epithelium (Brown 1982).

In conclusion, the community that forms on $\mathrm{CCA}$ treated wood responds to the presence of the 3 toxicants with decreased species richness, diversity, and biomass, and high accumulation of the contaminants. The presence of motile grazers on the panels (gobies, shrimp, and crabs) indicates a potential for metals accumulated in the epibiota to be passed into the general food web. There is, therefore, a likelihood of additional deleterious effects in the estuary, and the continued development of coastal areas with this material should be discouraged.
Acknowledgments. This research was supported by a grant from the Water Resources Program of the U.S. Geological Survey. We appreciate the hospitality of the Division of Natural Sciences of the Southampton Campus of Long Island University, and of Howard and Rosalind Mink for access to the marsh behind their property. We appreciate the technical assistance of Gregory Waldron and Theodore Proctor, and thank Elaine Hoagland for reviewing the manuscript

\section{LITERATURE CITED}

Brown, B. E. (1982). The form and function of metalcontaining 'granules' in invertebrate tissues. Biol. Rev. 57 $621-667$

Bryan, G. W., Hummerstone, L. G. (1973). Brown seaweed as an indicator of heavy metals in estuaries in South-west England. J. mar. biol. Ass. U. K. 53: 705-720

Denley, E. J., Underwood, A. J. (1979). Experiments on factors influencing settlement, survival, and growth of two species of barnacles in New South Wales. J. exp. mar. Biol. Ecol. 36: 269-293

Farrell, T M. (1991). Models and mechanisms of succession: an example from a rocky intertidal community. Ecol Monogr. 61: 95-11.3

Hall, A., Fielding, A. H., Butler, M. (1979). Mcchanisms of copper tolerance in the marine fouling alga Ectocarpus siliculosis - evidence for an exclusion mechanism. Mar. Biol. 54: 195-199

Ho, Y. B. (1990). Metals in Ulva lactuca in Hong Kong intertidal waters. Bull. mar. Sci. 47.79-85

Hoagland, K. E., Crocket, L. (1979). Analysis of populations of boring and fouling organisms in the vicinity of the Oyster Creek Nuclear Generating Station: Sept. 1, 1977-Aug. 31, 1978. Rept. to U.S. Nuc. Reg. Comm. NUREG/CR-0634, $114 \mathrm{pp}$

Loveland, R. E., Shafto, S. S. (1984) Fouling organisms. In Kennish, M., Lutz, R. (eds). Ecology of Barnegat Bay. Springer-Verlag, New York, p 226-236

Lund, U., Fobian, A. (1991). Pollution of two soils by arsenic, chromium, and copper, Denmark. Geoderma 49:83-103

Menge, B. A. (1991). Relative importance of recruitment and other causes of variation in rocky intertidal community structure. J. exp. mar. Biol. Ecol. 146: 69-100

Neary, D., Bush, P. B., Lafayette, R. A., Callaham, M. A., Taylor, J. W. (1989). Copper, chromium, arsenic, and pentachlorophenol contamination of a Southern Appalachian forest system. In: Weigmann, D. A. (ed.) Pesticides in terrestrial and aquatic environments. Virginia Water Resources Res. Ctr Publ. Serv., Blacksburg, p. $220-236$

Newell, A. V., Sanders, J. G. (1986). Relative copper binding capacities of dissolved organic compounds in a coastal plain estuary. Environ. Sci. Tech. 20: 817-820

Osman, R. W. (1977). The establishment and development of a marine epifaunal community. Ecol. Monogr. 47:37-63

Osman, R.W. (1978). The influence of seasonality and stability on the species equilibrium. Ecology 59: 383-399

Reed, R. H. Moffat, L. (1983). Copper toxicity and copper tolerance in Enteromorpha compressa (L) Grev. J exp mar. Biol. Ecol. 69: 85-103

Rittschof, D. Costlow, J. D. (1989). Bryozoan and barnacle settlement in relation to initial surface wettability: a comparison of laboratory and field studies. Scientia Mar. 53: $411-416$ 
Sanders, J. G., Riedel, G. F. (1987). Control of trace element toxicity by phytoplankton. In: Saunders, J. A., KosakChanning, L., Conn, E. E. (eds.) Phytochemical effects of environmental compounds. Plenum, New York, p 131-149

Sanders, J. G., Windom, H. L. (1980). The uptake and reduction of arsenic species by marine algae. Estuar. coast. mar. Sci. 10: 555-567

Sneddon, J., Pappas, G. (1991). Binding and removal of metal ions in solution by an algae biomass. Amer. Environ. Lab. 3 , \#4: $9-13$

Sousa, W. P. (1979). Experimental investigations of disturbance and ecological succession in a rocky intertidal algal community. Ecol. Monogr. 49: 227-254

Sutherland, J. P., Karlson, R. H. (1977). Development and stability of the fouling community at Beaufort, North Carolina. Ecol. Monogr. 47:425-446

U.S. Environmental Protection Agency (1990). Wood preserving; identification and listing of hazardous waste; final rule. Federal Register 55, No. 235: 50450-50490

This article was submitted to the editor
Warner, J. E., Solomon, K. R. (1990). Acidity as a factor in leaching of copper, chromium, and arsenic from CCAtreated dimension lumber. Environ. Toxicol. Chem. 9: $1331-1337$

Weis, J. S., Weis, P. (in press). Transfer of contaminants from CCA-treated lumber to aquatic biota. J. exp. mar. Biol. Ecol.

Weis, P., Weis, J. S., Coohill, L. (1991). Toxicity to estuarine organisms of leachates from chromated copper arsenate treated wood. Archs environ. Contam. Toxicol. 20: $118-124$

Weis, P., Weis, J. S., Greenberg, A., Nosker, $\Upsilon$ J (1992). Toxicity of construction materials in the marine environment: a comparison of chromated-copper-arsenatetreated wood and recycled plastic. Archs environ. Contam. Toxicol. 22: 99-106

White, K. B. (1990). Heavy metal accumulation by barnacles and its implications for their use as biological monitors. Mar. environ. Res. 30: 91-118

Manuscript first received: February 25, 1992

Revised version accepted: April 30, 1992 